\title{
NEW SYNTHESIS METHOD OF THE $\mathrm{Mg}_{2} \mathrm{Ni}$ COMPOUND BY USING MECHANICAL ALLOYING FOR HYDROGEN STORAGE
}

\author{
H. Suwarno ${ }^{1}$, W. Ari Adi ${ }^{2}$ and A. Insani ${ }^{2}$ \\ ${ }^{1}$ Center For Nuclear Fuel Technology \\ National Nuclear Energy Agency (BATAN) \\ Puspiptek Area, Serpong, Tangerang 15314 - Indonesia \\ ${ }^{2}$ Center For Technology of Nuclear Industry Material \\ National Nuclear Energy Agency (BATAN) \\ Puspiptek Area, Serpong, Tangerang 15314 - Indonesia
}

\begin{abstract}
NEW SYNTHESIS METHOD OF THE $\mathrm{Mg}_{2} \mathrm{Ni}$ COMPOUND BY USING MECHANICAL ALLOYING FOR HYDROGEN STORAGE. The synthesis and characterization of $\mathrm{Mg}_{2} \mathrm{Ni}$ compound by using mechanical alloying through wet method have been performed. The $\mathrm{Mg}_{2} \mathrm{Ni}$ sample was prepared by mixing the $\mathrm{Mg}$ and the $\mathrm{Ni}$ powders in the media of toluene under argon atmosphere. The mixtures are then milled under the varied milling time of $5,10,15,20$, and 25 hours in order to measure the growth of $\mathrm{Mg}_{2} \mathrm{Ni}$ compound. The X-ray diffraction measurement result showed that both $\mathrm{Mg}_{2} \mathrm{Ni}$ and $\mathrm{MgNi}_{2}$ crystals could grow well. From the refinement results of the X-ray diffraction pattern using Rietan analysis indicated that the fraction of $\mathrm{Mg}_{2} \mathrm{Ni}$ and $\mathrm{MgNi}_{2}$ compounds formed are $9.31 \%$ and $4.1 \%, 23.31 \%$ and $17.63 \%, 45.3 \%$ and $23.73 \%, 62.04 \%$ and $19.08 \%, 87.44 \%$ and $0.05 \%$ for the milling time of $5,10,15,20$, and 25 hours, respectively. This result differs from that obtained from the previous research, especially for 25 hours of milling time, the fraction of $\mathrm{Mg}_{2} \mathrm{Ni}$ and $\mathrm{MgNi}_{2}$ compounds formed were only reach $51.03 \%$ and $8.86 \%$, due to the growing of the pollutant phase like $\mathrm{MgO}$. The use of toluene as the media of milling succeeded to remove the growth of the $\mathrm{MgO}$ compound.
\end{abstract}

Keywords : $\mathrm{Mg}_{2} \mathrm{Ni}$, Growth, High energy milling

\section{INTRODUCTION}

The need of new energy resources have been the target of research in Indonesia recently. Since the PELITA (5 years development) programs were launched by the government of Indonesia on 1971 the use of fossil fuels in the form of oil and natural gas have powered the industrial and transportation network that drive the society. The supply of fossil fuel is limited with restrictive of shortages of oil and gas projected to occur within the country. Global oil and gas reserves are concentrated in a few region of the world while demands are growing everywhere; as a result a secure supply is increasingly difficult to assure. Moreover, the use of fossil fuels puts our own health at risk through the chemicals and particulate pollution.

One promising alternative to fossil fuels is hydrogen. Through its reaction with oxygen, hydrogen release energy explossively in heat engines or quietly in fuel cell to produce water as its only byproduct. 
Metal hydrides have the potential for reversible on-board hydrogen storage and release at low temperatures and pressures. Hydrogen storage in solids may make it possible to store larger quantities of hydrogen in smaller volumes at low pressure and at temperatures close to room temperature. It is also possible to achieve volumetric storage densities greater than liquid hydrogen because the hydrogen molecule is dissociated into atomic hydrogen within the metal hydride lattice structure.

Magnesium and its derived alloys are looked upon as promising candidates of hydorgen storage due to their high theoretical storage capacity (7.6 wt\%), light weight and low cost. However, high operating temperatures and slow kinetics prevent them from practical application[1,2].

Synthesis $\mathrm{Mg}_{2} \mathrm{Ni}$ compound has been researched by $\mathrm{H}$. Suwarno et al[3] recently. Mechanically dry state alloyed $\mathrm{Mg}_{2} \mathrm{Ni}$ compound was made using a high energy ball milling. The author reported that under a dry state the formation of $\mathrm{Mg}_{2} \mathrm{Ni}$ and $\mathrm{MgNi}_{2}$ compounds were disturbed by the formation of $\mathrm{MgO}$.

A new method is developed to avoid the formation of $\mathrm{MgO}$ during milling. The $\mathrm{Mg}$ and $\mathrm{Ni}$ powders with the atomic ratio of 2:1 are mixed together in a milling holder and then a toluene solution is poured in the holder. The holder then put in the milling vial and followed by purging the vial with argon. It is called the wet process.

The Mg-Ni compounds after milling using a high energy mechanical milling are analyzed by X-Ray diffractometer (XRD) and Rietan Program and presented in this manuscript.

\section{EXPERIMENTAL METHODS}

The $\mathrm{Mg}_{2} \mathrm{Ni}$ compound was prepared by solid state reaction by mixing the elemental constituent of $\mathrm{Mg}$ obtained from Merck with purity of $99.85 \%$, $<3.5 \mu \mathrm{m}$ and Ni obtained from Merck with purity of $99.0 \%,<10 \mu \mathrm{m}$, with atomic ratio of $2: 1$ by reaction as follows:

$$
2 \mathrm{Mg}+\mathrm{Ni} \rightarrow \mathrm{Mg}_{2} \mathrm{Ni}
$$

The milling machine used in the experiment is a high energy milling (HEM) Spex type 8000 with the specification of machine as $4500 \mathrm{rpm}$ at normal blending speed, run time 90 minutes, off time 30 minutes. This is called one cycle of milling. The HEM consists of a vial which is filled with balls moving spinally to comminute the powder of initial specimens into nanosize particles. The vials were made from stainless steel wih the diameter of $5.1 \mathrm{~cm}$ and $7.6 \mathrm{~cm}$ in length. The balls are made from stainless steel with the diameter of balls is $12 \mathrm{~mm}$. About 15 grams of $\mathrm{Mg}$ and $\mathrm{Ni}$ elements with atomic ratio of $\mathrm{Mg}: \mathrm{Ni}=2: 1$ are mixed together with balls and poured into the 
vial. The ball to specimens ratio is 8 . The varied milling time selected are $5,10,15,20$, and 25 hours at room temperature.

Qualitative and quantitative analyses used in the experiment were conducted in an X-ray Diffractometer, Philip, type PW1710, using $\mathrm{Cu}$ as the anode tube and $\lambda=1.5406 \AA$. Continuous scanning were conducted at $0.02^{\circ}$ step size and 0.5 second/step. The scanning results are analyzed by a Rietan code developed by Fuji Izumi[4]. The first data contains parameter of the crystal structure and the second is the data of intensity. The Rietan code then gives information about the crystal strucutural parameter in a unit of a cell, intensity of the calculation and observation, number of mass fraction if the sample contains more than one compounds, and the data of Bragg reflection.

\section{RESULTS AND DISCUSSION}

Measurement results of the specimens using XRD for wet samples under milling process and varied milling time of 5, 10, 15, 20, and 25 hours are presented in Figure 1.

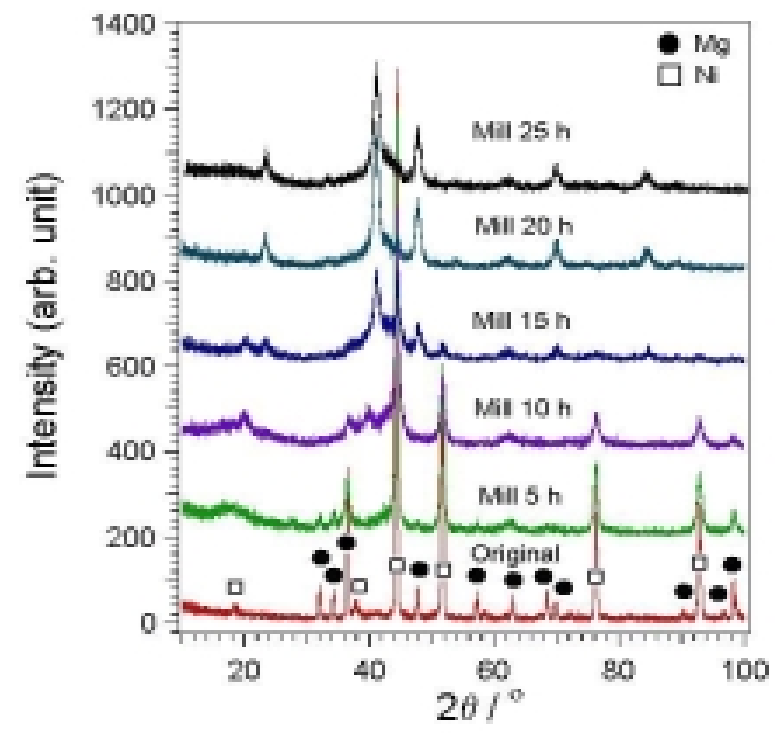

Figure 1. XRD profiles on milling time of $0,5,10,15,20$, and 25 hours, wet process.

Compared to the previous experimental results, presented in Figure 2, it is showed that no $\mathrm{MgO}$ compound is observed. Figure 2 is almost dominated with the $\mathrm{MgO}$, while none in Figure 1. 


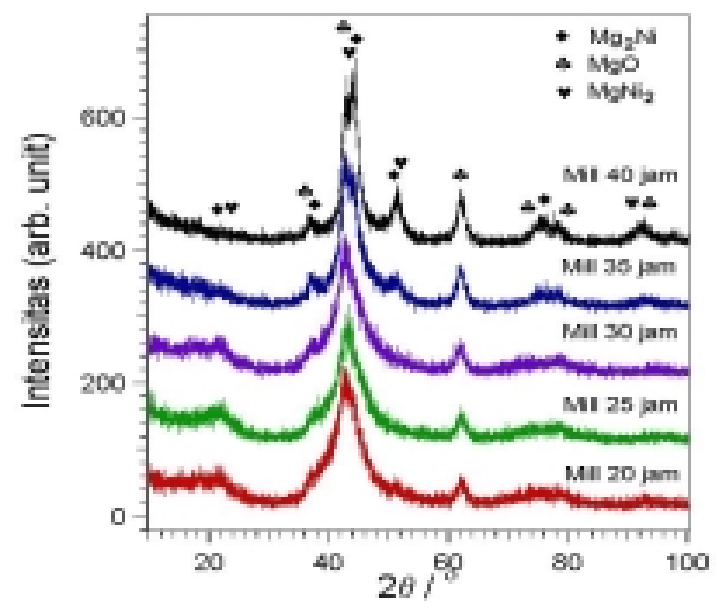

Figure 2. XRD profiles on dry process for milling times of 20, 25, 30, 35, and 40 hours[3].

Figure 3 shows the XRD profiles of the Mg-Ni sample before milling after refinement using Rietan code.

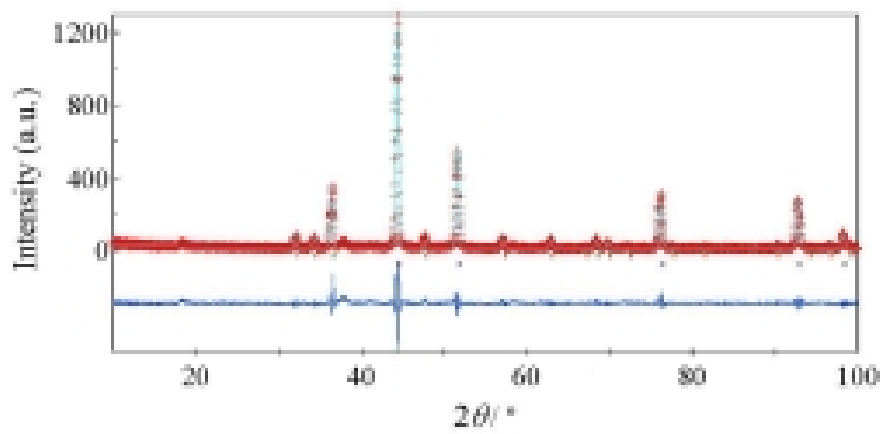

Figure 3. Refinement results of the XRD profiles on $\mathrm{Mg}-\mathrm{Ni}$ powder before milling.

Figure 3 shows that it is consisted of the XRD profiles of the observation (notated with symbol plus, +), calculation (notated with symbol minus, -), dots of the peak phases or Miller index (notated with symbol 1), and the difference between the calculation and the observation (notated with symbol -). The last curve is used for expressing the quality of fitting of the XRD observation and calculation one. The flat or the stright line of the last curve exhibits the best quality of fitting. It means that the sample prepared similar to the standard reference[5]. 
Figure 1 shows that it is in accordance with the Hanawalt's table where during milling time of $5,10,15,20$, and 25 hours the sample consisted of four phases, i.e. $\mathrm{Mg}_{2} \mathrm{Ni}, \mathrm{MgNi}_{2}, \mathrm{Mg}$ and $\mathrm{Ni}$. The mass fraction of each phase is presented in Figures 4, 5, 6, 7 and 8.

Figure 4 shows that the peaks of the diffraction profile of the analytical result coinside with that of $\mathrm{Mg}_{2} \mathrm{Ni}, \mathrm{MgNi}_{2}, \mathrm{Ni}$, and $\mathrm{Mg}$ phases. It means that the sample after 5 hours of milling contains four phases.

Figure 5 shows the XRD profile of the sample after 10 hours of milling refined using the Rietan code.

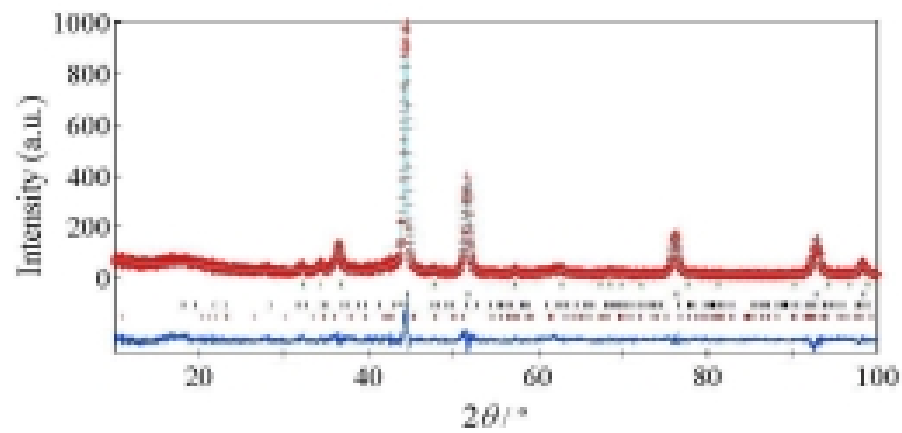

Figure 4. The refinement result of the XRD profile for $\mathrm{Mg}_{2} \mathrm{Ni}$ compound after 5 hours of milling.

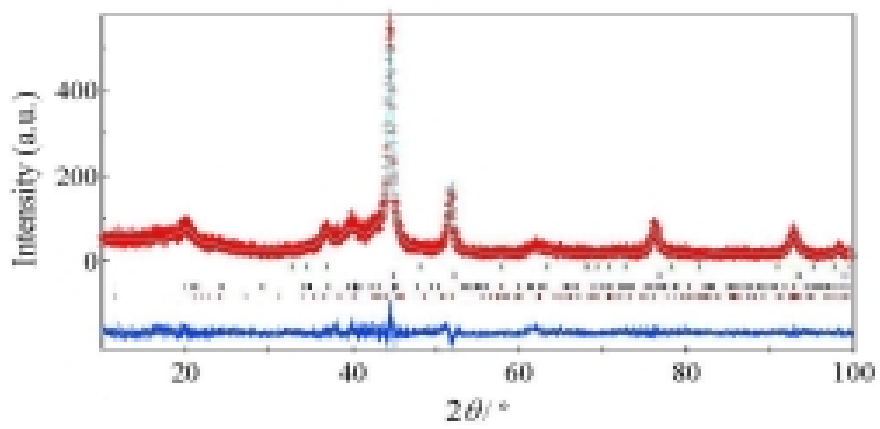

Figure 5. The refinement result of the XRD profile for $\mathrm{Mg}_{2} \mathrm{Ni}$ compound after 10 hours of milling.

Figure 6 showed the XRD profile for $\mathrm{Mg}_{2} \mathrm{Ni}$ sample after 15 hours of milling refined using the Rietan code. 


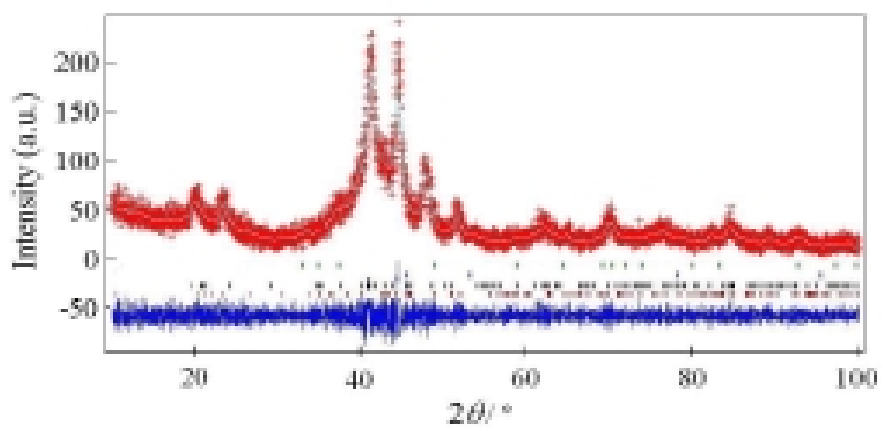

Figure 6. The refinement result of the XRD profile for $\mathrm{Mg}_{2} \mathrm{Ni}$ compound after 15 hours of milling

Figure 7 shows the XRD profile for $\mathrm{Mg}_{2} \mathrm{Ni}$ sample after 20 hours of milling refined using the Rietan code.

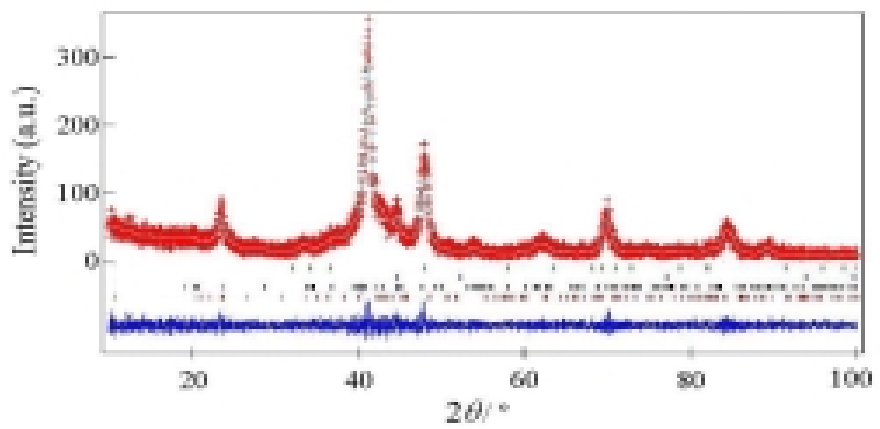

Figure 7. The refinement result of the XRD profile for $\mathrm{Mg}_{2} \mathrm{Ni}$ compound after 20 hours of milling.

Figure 8 shows the XRD profile for $\mathrm{Mg}_{2} \mathrm{Ni}$ sample after 25 hours of milling refined using the Rietan code. 


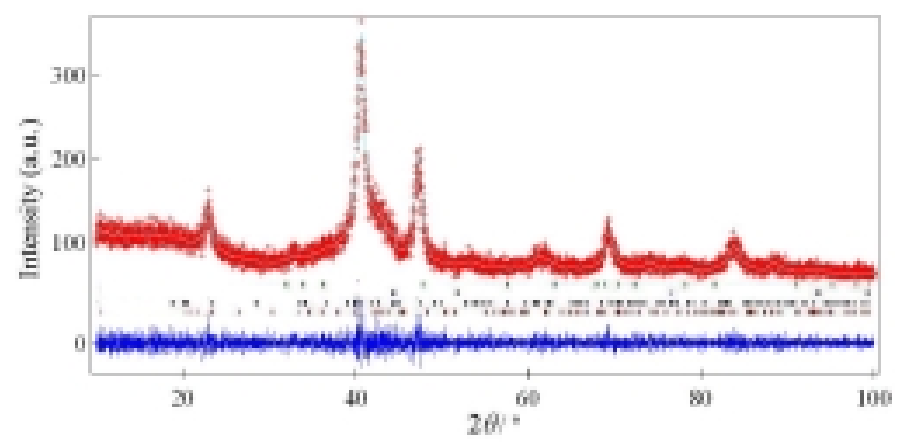

Figure 8. The refinement result of the XRD profile for $\mathrm{Mg}_{2} \mathrm{Ni}$ compound after 25 hours of milling.

Figures $4,5,6,7$, and 8 show that the difference between the calculation and the observation are so small or fitting of each sample after milling time of 5, 10, 15, 20, and 25 hours is in good agreement.

Table 1 presents the lattice parameters for $\mathrm{Mg}_{2} \mathrm{Ni}$ and $\mathrm{MgNi}_{2}$ phases after $5,10,15,20$, and 25 hours of milling and Table 2 presents the data for criteria of fit dan goodness of fit for $\mathrm{Mg}, \mathrm{Ni}, \mathrm{Mg}_{2} \mathrm{Ni}$, and $\mathrm{MgNi}_{2}$ phases after $5,10,15,20$, and 25 hours of milling $\left(\mathrm{R}_{\mathrm{wp}}=\right.$ Ratio weight pattern or criteria of fit, $S=$ goodness of fit, $R_{I}=$ ratio intensity, $R_{F}=$ ratio fit $)$.

Table 1. Lattice parameter data for $\mathrm{Mg}_{2} \mathrm{Ni}$ and $\mathrm{MgNi}_{2}$ phases after $5,10,15,20$, and 25 hours of milling.

\begin{tabular}{|c|c|c|c|c|c|c|}
\hline \multirow{2}{*}{$\begin{array}{c}\text { Milling } \\
\text { time }\end{array}$} & \multicolumn{2}{|c|}{ Lattice parameter of $\mathrm{Mg}_{2} \mathrm{Ni}$} & \multicolumn{3}{c|}{ Lattice parameter of $\mathrm{MgNi}_{2}$} \\
\cline { 2 - 7 } & $\mathrm{a}$ & $\mathrm{b}$ & $\mathrm{c}$ & $\mathrm{a}$ & $\mathrm{b}$ & $\mathrm{C}$ \\
\hline $5 \mathrm{hrs}$ & $5.670(8)$ & $5.670(8)$ & $12.282(5)$ & $4.969(5)$ & $4.969(5)$ & $16.234(7)$ \\
\hline $10 \mathrm{hrs}$ & $5.295(2)$ & $5.295(2)$ & $12.679(8)$ & $4.927(1)$ & $4.927(1)$ & $16.199(7)$ \\
\hline $15 \mathrm{hrs}$ & $5.102(4)$ & $5.102(4)$ & $12.796(1)$ & $4.942(2)$ & $4.942(2)$ & $16.117(6)$ \\
\hline $20 \mathrm{hrs}$ & $5.026(5)$ & $5.026(5)$ & $13.592(1)$ & $4.973(5)$ & $4.973(5)$ & $16.007(8)$ \\
\hline $25 \mathrm{hrs}$ & $5.036(1)$ & $5.036(1)$ & $13.972(3)$ & $5.470(9)$ & $5.470(9)$ & $15.067(7)$ \\
\hline
\end{tabular}

Table 2. Criteria of fit $\left(\mathrm{R}_{\mathrm{wp}}\right)$ dan goodness of fit ( $\left.\mathrm{S}\right)$ data for $\mathrm{Mg}, \mathrm{Ni}, \mathrm{Mg}_{2} \mathrm{Ni}$, and $\mathrm{MgNi}_{2}$ phases after 5,10,15,20, and 25 hours of milling.

\begin{tabular}{|c|c|c|c|c|c|c|c|c|c|c|}
\hline \multirow{2}{*}{$\begin{array}{c}\text { Milling } \\
\text { time }\end{array}$} & $\mathrm{R}_{\mathrm{wp}}$ & \multicolumn{2}{|c|}{$\mathrm{Mg}$} & \multicolumn{2}{c|}{$\mathrm{Ni}$} & \multicolumn{2}{c|}{$\mathrm{Mg}_{2} \mathrm{Ni}$} & \multicolumn{2}{c|}{$\mathrm{MgNi}_{2}$} & $\mathrm{~S}$ \\
\cline { 3 - 11 } & & $\mathrm{R}_{\mathrm{I}}$ & $\mathrm{R}_{\mathrm{F}}$ & $\mathrm{R}_{\mathrm{I}}$ & $\mathrm{R}_{\mathrm{F}}$ & $\mathrm{R}_{\mathrm{I}}$ & $\mathrm{R}_{\mathrm{F}}$ & $\mathrm{R}_{\mathrm{I}}$ & $\mathrm{R}_{\mathrm{F}}$ & \\
\hline $5 \mathrm{hrs}$ & 19.75 & 11.37 & 5.62 & 6.26 & 2.85 & 12.58 & 5.44 & 13.63 & 5.94 & 1.27 \\
\hline $10 \mathrm{hrs}$ & 17.42 & 5.40 & 3.11 & 4.15 & 2.33 & 6.94 & 3.48 & 4.96 & 2.94 & 1.11 \\
\hline $15 \mathrm{hrs}$ & 22.75 & 9.73 & 9.37 & 12.27 & 10.02 & 12.41 & 9.96 & 15.02 & 10.36 & 1.41 \\
\hline $20 \mathrm{hrs}$ & 29.76 & 50.58 & 28.38 & 24.09 & 11.55 & 21.77 & 11.25 & 27.95 & 14.32 & 1.79 \\
\hline $25 \mathrm{hrs}$ & 36.37 & 50.84 & 30.59 & 21.38 & 12.28 & 28.48 & 18.25 & 64.87 & 37.93 & 2.05 \\
\hline
\end{tabular}


Table 3 presents the mass fraction of $\mathrm{Mg}, \mathrm{Ni}, \mathrm{Mg}_{2} \mathrm{Ni}$ and $\mathrm{MgNi}_{2}$ phases after 5, 10, 15, 20, and 25 hours of milling.

Table 3. Mass fraction of $\mathrm{Mg}, \mathrm{Ni}, \mathrm{Mg}_{2} \mathrm{Ni}$, and $\mathrm{MgNi}_{2}$ phases after 5, 10, 15, 20 , and 25 hours of milling.

\begin{tabular}{|c|c|c|c|c|}
\hline Milling & \multicolumn{4}{|c|}{ Mass fraction of each phase (\%) } \\
\cline { 2 - 5 } time, hrs & $\mathrm{Mg}$ & $\mathrm{Ni}$ & $\mathrm{Mg}_{2} \mathrm{Ni}$ & $\mathrm{MgNi}_{2}$ \\
\hline $5 \mathrm{hrs}$ & 17.9 & 68.63 & 9.37 & 4.1 \\
\hline $10 \mathrm{hrs}$ & 12.56 & 46.5 & 23.31 & 17.63 \\
\hline $15 \mathrm{hrs}$ & 4.78 & 26.19 & 45.3 & 23.73 \\
\hline $20 \mathrm{hrs}$ & 5.38 & 13.5 & 62.04 & 19.08 \\
\hline $25 \mathrm{hrs}$ & 2.16 & 10.35 & 87.44 & 0.05 \\
\hline
\end{tabular}

In the region of $20^{\circ}$ it is showed clearly that when the sample was milled for 5 hours the peaks start to grow identified as $\mathrm{Mg}_{2} \mathrm{Ni}$ and $\mathrm{MgNi}_{2}$ phases. The peaks grow steeply after 15 hours of milling where the peak for $\mathrm{MgNi}_{2}$ seems to be more dominant. After 20 and 25 hours of milling the peaks identified for $\mathrm{MgNi}_{2}$ reduce and the peaks identified for $\mathrm{Mg}_{2} \mathrm{Ni}$ grow dominantly. Similar peaks can be observed also in the region of $40^{\circ}$. In this region the strongest peak come from the $\mathrm{Mg}_{2} \mathrm{Ni}$ phase after 10 hours of milling and become stronger after 25 hours of milling. It can be proved from the refinement profiles of the XRD for each milling time as presented in Table 3.

Figure 9 presents the curve of milling time versus mass fraction of each phase.

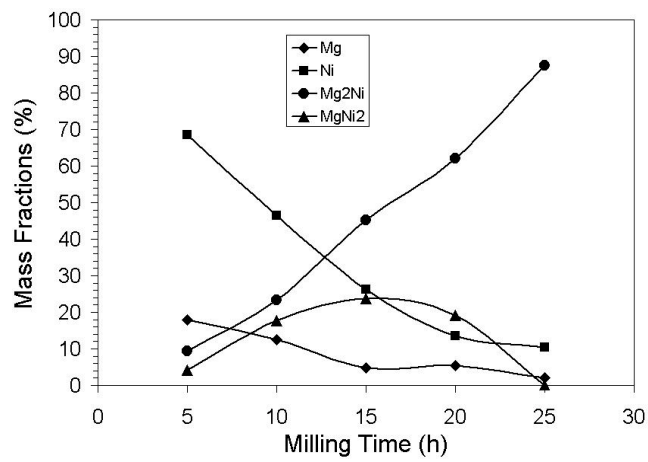

Figure 9. Milling time versus mass fraction obtained for the four phases.

From Figure 9 it is showed that the metastable $\mathrm{MgNi}_{2}$ phase will decompose into more stable form of $\mathrm{Mg}_{2} \mathrm{Ni}$ phase. Consequently, the highest mass fraction of the $\mathrm{Mg}_{2} \mathrm{Ni}$ phase will reduce the mass fraction of $\mathrm{MgNi}_{2}$ 
phase up to $<1 \%$ and $\mathrm{Mg}$ to $<3 \%$. This situation will result in the difficulties to do refining the XRD data and consequently the criteria of fit $\left(\mathrm{R}_{\mathrm{wp}}\right)$ and the goodness of fit (S) after 20 and 25 hours of milling increase. Rietan program cannot refine phases with mass fraction of $<5 \%$ and if this situation is encountered it could be neglected. It is concluded that the wet method of milling using toluene will protect the sample from its interaction with oxygen and the $\mathrm{Mg}_{2} \mathrm{Ni}$ phase could grow well.

\section{CONCLUSION}

The synthesis and characterization of $\mathrm{Mg}_{2} \mathrm{Ni}$ compound by using mechanical alloying through wet method have been performed. Refinement results of the XRD profiles showed that the fitting between observation and calculation are in good agreement and after milling the sample can be identified into of four phases namely $\mathrm{Mg}, \mathrm{Ni}, \mathrm{Mg}_{2} \mathrm{Ni}$, and $\mathrm{MgNi}_{2}$ compounds. The mass fraction of $\mathrm{Mg}_{2} \mathrm{Ni}$ increase up to $87.44 \%$ after 25 hours of milling an indication that the wet method is more effective than the dry one.

\section{ACKNOWLEDGEMENT}

The authors would like to express our thank to the State Ministry of Research and Technology for its support by providing the budget for this reseach under the Program Insentif, KNRT, 2007. Thank also addressed to PT. BATAN Teknologi on providing facilities and support to this research program.

\section{REFERENCES}

1. REILLY, J.J AND WISWALL, R.H., Inorg.Chem., 6, 2220 (1967).

2. DARRIET, B, PEZAL, M et al, Int. J. Hydrogen Energy, N2, 173 (1980).

3. SUWARNO, $\mathrm{H}$ et al, "The X-Ray Diffraction Analysis on the Mechanical Alloying of the Mg2Ni Formation", presented in the 2007 Conference on Solid State Ionics in Conjunction with Scientific Gathering on the International Joint Research program, August 1-3, 2007, National Reserach Council Puspiptek, Tangerang, Indonesia.

4. IZUMI, F, "Rietan Manual” (private communication) (1994).

5. GAFFET E., Mechanosysthesis : What does It Mean? (Mechanical Alloying, Ball Milling and Attrition), http://www. mechanosynthesisWhatdoesItMean.html, (2006). 